\title{
Digitale spil i undervisningen
}

\section{Overblik over et broget landskab}

Thorkild Hanghøj, Aalborg Universitet

\begin{abstract}
Forskningen i anvendelsen af digitale spil i undervisningen har flere årtier på bagen og vidner om positive resultater med øget motivation og læringsudbytte. Samtidig er der ofte uklarhed om de didaktiske muligheder og begrænsninger, der knytter sig til forskellige måder at anvende digitale spil i undervisningen. I denne oversigtsartikel vil jeg først indkredse, hvad der kendetegner digitale spil og kort opsummere forskningen i spil og læring. Dernæst vil jeg give et overblik over den danske forskning i fire forskellige didaktiske tilgange til digitale spil i undervisningen: 1) anvendelse af læringsspil, 2) anvendelse af kommercielle computerspil, 3) brug af spilelementer i ikke-spil sammenhænge (gamification), og 4) arbejde med design af spil. Undervejs vil jeg give uddybende eksempler på dansk forskning inden for området, herunder artikler fra Læring Og Medier samt egen forskning. Ambitionen er at præsentere et overblik over den danske forskning i brug af digitale spil i undervisningen, der kan bidrage til at kvalificere didaktiske valg ved udvælgelse og anvendelse af spil.
\end{abstract}

\section{Engelsk abstract}

Research on the educational use of digital games has been going on for several decades and shows positive results in terms of increased motivation and learning outcomes. However, the challenges and possibilities of using games in education are often unclear. In this paper, I will briefly define games and summarise the research on games and learning. Next, I will provide an overview of Danish research on four different approaches to teaching with digital games: 1) the use of learning games, 2) the use of commercial games, 3) the use of game elements in non-game contexts (gamification), and 4) working with design of games. I will provide examples on Danish research, including articles from Læring Og Medier as well as from my own research. The aim of is to present an overview of the Danish research within the field, which can contribute to qualifying the selection and facilitation of games for educational purposes. 


\section{Indledning}

Digitale spil i undervisningen er et broget fænomen med mange ansigter. I Læring Og Medier er der eksempelvis publiceret artikler om didaktisering af kommercielle computerspil som Minecraft og Penumbra i danskundervisningen (Hanghøj, 2012), om anvendelse af digitale læringsspil til at undervise erhvervsskoleelever om dilemmaer i deres arbejdsmiljø (Meldgaard et al., 2016), om brug af en gamification app på Fysioterapeutuddannelsen (Ahler \& Bader, 2015), og om ingeniørstuderendes udvikling af egne spil med spildesignværktøjet Gamemaker (Majgaard, 2012). Som eksemplerne antyder findes der forskning i flere forskellige tilgange til digitale spil og spilredskaber på tværs af en række forskellige læringskontekster - lige fra folkeskole over professionsuddannelser til universitetsniveau.

Formålet med denne artikel er at give et overblik over forskningen i digitale spil i undervisningen og dermed give læseren mulighed for at navigere i et broget landskab. De to spørgsmål jeg vil undersøge er: Hvad ved vi om spil og læring, og hvilke didaktiske muligheder og begrænsninger er der forbundet med forskellige tilgange til digitale spil i undervisningen? Undervejs vil jeg inddrage international forskning på området, men primært fokusere på den danske forskning, heriblandt min egen forskning og den forskning som er blevet udgivet i Læring Og Medier. Artiklen er bygget op som en gennemgang af fire forskellige didaktiske tilgange til digitale spil i undervisningen: læringsspil, kommercielle computerspil, gamification og design af spil. Der er tale om en pragmatisk opdeling, som bygger videre på studier af, hvordan undervisere arbejder med spil i praksis (se f.eks. Nousiainen et al. 2018). Der er ikke tale om et systematisk review af al relevant forskning på området, men et forsøg på at skabe overblik over et uoverskueligt landskab med mange konfigurationer af forskellige spildesigns og didaktiske fremgangsmåder. Jeg slutter artiklen med at opsummere tværgående temaer for de didaktiske muligheder og begrænsninger ved at anvende digitale spil i undervisningen.

\section{Hvad er spil?}

Spil er interaktive fænomener med stor indbyrdes variation, der både kan forstås som konkrete designs (dvs. som tekster, produkter, artefakter og/eller systemer) og som aktiviteter (dvs. som processer eller praksisser), der er indlejrede i bestemte kulturelle sammenhænge. Der findes talrige forsøg på at definere, hvad der kendetegner digitale spil (se f.eks. Juul, 2005; Salen \& Zimmerman, 2003). Kort opsummeret er de fleste definitioner enige om, at spil giver mulighed for at interagere med og udforske udfordringer med klare mål og udfald. Et spil kan f.eks. gå ud på at kunne besejre en modstander, bygge konstruktioner eller udforske en verden. For at håndtere udfordringen tilbyder spil en række interaktive handlemuligheder (spilmekanikker), som er styret af regler og giver feedback i takt med spillerens progression. I modsætning til analoge spil giver algoritmerne i digitale spil automatiseret feedback på spillerens handlinger - f.eks. kan en tutorial bane hurtigt hjælpe en ny spiller til at lære spillet. Dertil kommer det audiovisuelle udtryk og narrative forløb i digitale spil, som løbende ændrer sig i takt med spillerens udforskning.

Som allerede Goffman (1961) gjorde opmærksom på i sit studie af social interaktion i brætspil og kortspil, bør det imidlertid understreges, at spil ikke kan forstås alene ud fra spillerens formelle handlemuligheder ud fra spildesignets mål og regler. Spil realiseres gennem sociale og legende aktiviteter, hvor det i høj grad er deltagerne, som selv er med til at definere, forhandle og omforme, hvad der tæller og ikke tæller som en del af spillets forståelsesramme. Betoningen af den sociale kontekst bliver endnu vigtigere, når man anvender spil til didaktiske formål, eftersom deltagerne ofte vil bevæge sig ud og ind af flere forskellige forståelsesrammer - som biografisk person, som figur i spillet med bestemte handlemuligheder, som spiller der agerer gennem figuren og som lærende (Hanghøj, 2008). I denne artikel vil jeg derfor ikke gå yderligere i dybden med at definere elementerne i spil, eftersom mit fokus primært er at forstå den didaktiske anvendelse af digitale spil. 
Kigger man ud over det brogede landskab af digitale spildesigns, der anvendes i undervisningen, kan man groft skelne mellem fire typer af spilredskaber: læringsspil, kommercielle computerspil, gamification platforme og programmer til spildesign. Men eftersom spildesigns altid realiseres i lokale læringskontekster ud fra underviseres konkrete didaktiske valg, der har stor betydning for både de lærendes engagement og læringsudbytte, er det problematisk at reducere spilbaseret læring alene til et spørgsmål om at udvælge og bruge bestemte spildesigns. For at undgå en instrumentel reduktion af spilbaseret læring til teknologibrug, arbejder jeg derfor med en pragmatisk forståelse af forskellige didaktiske tilgange til spil i undervisningen. Dermed forsøger jeg både at medtænke de læringsmæssige muligheder og begrænsninger i bestemte spildesigns og i de måder, hvorpå spillene realiseres i undervisningen gennem didaktiske praksisser.

\section{Hvordan kan man lære gennem spil?}

Den mest citerede forsker inden for spil og læring, James Paul Gee (2007), præsenterer ikke færre end 16 principper for, hvordan man kan lære gennem spil. Det er især relevant at fremhæve oplevelsen af kunne interagere med spil, som gør det muligt at være medskaber af spillets verden; at agere gennem en projiceret identitet, hvor man kan afprøve og reflektere over andre versioner af sig selv; at kunne møde og håndtere konkrete problemer, som samtidig kan være komplekse og dybe; og at kunne fejle uden alvorlige konsekvenser for derefter at kunne forsøge igen. Gees principper er brugbare pejlemærker til at forstå, hvordan man kan lære gennem spil. Alle principperne kommer dog langt fra til udtryk i alle spildesigns. Samtidig kommer Gee kun med få anvisninger på, hvordan principperne kan omsættes til en didaktisk kontekst.

For at forstå hvordan man kan lære gennem digitale spil, er det nødvendigt at have et grundlæggende kendskab til spilmekanikker og udfordringer i konkrete spildesign for at kunne vurdere, hvordan de kan bruges til at indfri forskellige læringsmål. Eksempelvis er det vigtigt at kende bevægelsesmulighederne i exergamet Dance Dance Revolution, hvis spillet skal bruges at træne kondition; have kendskab til spilmekanikkerne i strategispillet Dice War, hvis man vil bruge det til at udvikle elevers evner til logisk tænkning i matematikundervisningen; have erfaring med at klare motoriske og taktiske udfordringer i Counter-Strike, hvis spillet skal bruges til at udvikle spillernes evner til samarbejde og kommunikation; og forstå sværhedsgrader og progressionsmønstre i gamification platformen Duolingo for at anvende spilaktiviteterne i fremmedsprogsundervisningen.

Uanset om der er tale om et læringsspil eller ej, rummer alle spildesigns bestemte antagelser om og modeller for, hvordan spillerne skaber viden, gør sig erfaringer og afprøver værdier gennem spillet. Når man undersøger de læringsmæssige muligheder i et spil er der derfor flere forskellige parametre, som kan være relevante at medtænke - herunder både de kognitive, affektive, motivationsmæssige og sociokulturelle aspekter af spildesignet (Plass et al., 2015). Dvs. hvordan spilleren bliver stilladseret til at danne ny viden gennem spillet; hvilke værdier og følelser som spilleren kan aktualisere i spillet; hvordan spildesignet kan motivere spilleren til at foretage bestemte handlinger, og hvordan spillet indgår i bestemte sociale og kulturelle læringskontekster.

I praksis kan det være vanskeligt at adskille de læringsmæssige aspekter i et spildesign, eftersom de ofte er overlappende eller bygger på hinanden. Jeg vil derfor med afsæt i Sfards (1998) to metaforer for læring lave en overordnet skelnen mellem didaktiske perspektiver på spil, der primært lægger vægt på læring gennem tilegnelse af viden eller læring gennem deltagelse $i$ en social kontekst. Mange former for læringsspil og gamification teknologier giver primært den lærende mulighed for at tilegne sig ny viden - f.eks. gennem at øve sproglige eller matematiske færdigheder, udvikle ny begrebsforståelse af globale konflikter eller repetere viden om den menneskelige anatomi. Omvendt lægger anvendelsen af itstøttede rollespil, multiplayer computerspil eller udvikling af spildesigns i højere grad op til, at spillerne udvikler viden gennem fælles social konstruktion, hvor deltagerne sammen skaber eller udforsker specifikke spilverdener. Af samme grund er det centralt at skelne mellem singleplayer og multiplayer 
spil, eftersom de to former for interaktion indebærer vidt forskellige muligheder for læring og konstruktion af viden. Ligesom Sfard ønsker jeg ikke at fremhæve den ene metafor for læring på bekostning af den anden, eftersom begge perspektiver er væsentlige i forhold til at forstå, hvordan man kan skabe ny viden gennem spil. Min pointe er blot, at specifikke spildesigns ofte betoner det ene syn på læring frem for det andet. Den vægtning influerer samtidig de didaktiske muligheder og begrænsninger i forhold til at anvende spillene i undervisningen.

Uanset hvad man forstår ved "spil" og ved "læring", kræver brugen af spil i undervisningen, at man som underviser nøje undersøger og støtter koblingen mellem spillets mål og faglige mål. Det er langt fra en selvfølge, at der er overensstemmelse mellem de to typer af mål. Som eksempel er læringsspil ofte så fokuserede på at føre spilleren frem til et bestemt læringsmål, at det kan begrænse handlemulighederne og gøre det svært at motivere spilleren over længere tid. Omvendt kan det være vanskeligt at identificere koblinger til specifikke læringsmål, når man underviser med kommercielle computerspil, eftersom spillenes komplekse verdner er designet til underholdning og ikke til at blive anvendt som læringsredskab. Der findes ingen nemme opskrifter på at designe eller anvende spil til at indfri mål i undervisningen; det er et forhold, som løbende skal konfigureres af underviseren i spændet mellem læringsmulighederne i bestemte spildesigns, didaktiske intentioner og konkret praksis.

Selvom den empiriske forskning i spil og læring har flere årtier på bagen, tegner resultaterne et billede, der er lige så broget, som der findes forskellige typer af spildesigns. Den store variation gælder både den danske og den internationale forskning. En af årsagerne til variationen er, at der er stor forskel på forskernes metoder til at studere spil og læring, som dækker lige fra læringsteoretiske analyser og etnografiske studier over design-orienterede tilgange til at gennemføre effektmålinger. Der findes imidlertid en række systematiske reviews, som forsøger at skabe overblik over forskningen i spilbaseret læring. Et omfattende review af læringseffekterne ved brug af digitale spil i undervisningen konkluderer således, at både den konkrete udformning af spillenes design og selve faciliteringen af spillene har stor betydning i forhold til at kunne øge læringsudbyttet (Clarke et al., 2016). Dette resultat understreger vigtigheden af ikke kun at tage afsæt i de affordances, som knytter sig til bestemte spildesigns, men i stedet fokusere bredere på forskellige didaktiske tilgange til spil.

Et andet review fokuserer i højere grad på, hvilken rolle motivation spiller ved brug af læringsspil (Wouters et al., 2013). Forfatterne konkluderer, at brugen af digitale læringsspil kan bidrage til at øge fagligt læringsudbytte samt retention i forhold til andre undervisningsmetoder, men at det øgede læringsudbytte ikke nødvendigvis hænger sammen med øget motivation. Dette resultat går imod den udbredte myte, at spilbaseret læring primært er et spørgsmål om at kunne motivere de lærende. Mine egne studier i Sæt skolen i spil (2015-2017) projektet viste tilsvarende, at selvom eleverne i høj grad blev motiveret til at samarbejde gennem co-op computerspillet Torchlight II, så var der stor forskel på, om eleverne kunne koble deres spiloplevelse til en øget faglig motivation gennem at arbejde med spilrelaterede opgaver i dansk og matematikundervisningen (Hanghøj et al., 2018). Flere studier peger derfor på, at elever motiveres meget forskelligt gennem spil, og at spilbaseret motivation ikke blot er en knap, som man kan skrue op for og derved opnå større læringsudbytte.

Det er en udbredt antagelse, at digitale spil er velegnede til at udvikle 21st Century Skills som samarbejde, kommunikation, kreativitet og kritisk tænkning. En gennemgang af den empiriske forskning påviser, at det især er gennem design af egne spil, at studerende opnår positive effekter i forhold til at udvikle 21st Century Skills (Qian \& Clark, 2016). Det vidner om, at det i mange sammenhænge kan være mere lærerigt at (re-)designe et spil i stedet for at anvende eksisterende spil bl.a. fordi at man som designer skal kunne håndtere stor kompleksitet og træffe mange forskellige valg. Hvad angår anvendelsen af digitale spil til læring i skolefag, konkluderer et review af Young et al. (2012), at brugen af spil kun i begrænset grad ser ud til at øge læringsudbyttet i fag som matematik og naturfag, men at der især er positive læringseffekter ved brug af spil, når de anvendes til undervisning i fremmedsprog, historie og idræt. Der er dermed tegn på, at det kan være lettere eller mere meningsfuldt at skabe koblinger mellem spildesigns og faglige mål i bestemte skolefag frem for andre. 
Fælles for de ovennævnte reviews gælder, at de alle tilskriver underviseren en afgørende rolle i forhold til at anvende spil i undervisningen. Der nævnes mange forskellige faktorer, som kan påvirke faciliteringen af spilbaseret undervisning. Underviseren bør først og fremmest være fortrolig med spillet, og hvordan det skal bringes i anvendelse. Derudover bør underviseren have godt kendskab til det faglige emne, som spillet relateres til. Det har også betydning, hvordan spillet introduceres i undervisningen, samt hvor ofte og hvor meget der spilles. I deres gennemgang af processen med at anvende spil i undervisningen beskriver Kangas et al. (2017), hvordan undervisere ofte bevæger sig fra en 1) planlægningsfase, hvor de udvælger spil, en 2) orienteringsfase i starten af et spilforløb, der knytter spillet til bestemte mål, en 3) spilfase, hvor spillet faciliteres, og til sidst en 4) evalueringsfase, der samler op på spillets erfaringer og knytter dem til faglige mål.

I min egen forskning har jeg tilsvarende beskrevet, hvordan underviseres spilkompetence både afhænger af deres game literacy og gamemastering (Hanghøj \& Møller, 2017). Dvs. en kombineret evne til at kunne afkode, spille og mestre et spil - og samtidig at kunne bringe spillet til live og orkestrere dialog i relation til spillet. Der kan være endog stor forskel på, hvordan undervisere tilgår det samme spil og kobler spillets udfordringer til bestemte faglige og pædagogiske mål. Som eksempel valgte tre teams af dansklærere tre væsentligt forskellige tilgange til at anvende det samme Minecraft forløb i indskolingen (Hanghøj, 2017a). Det ene team afviklede primært spillet som en film eller en anden multimodal fortælling uden at fokusere på spillets interaktive aspekter og elevernes samarbejde omkring deres konstruktioner. Det andet team improviserede sig frem ud fra en fascination af elevernes kunnen i spillet, men lærerne tabte undervejs de faglige mål af syne. Det tredje team transformerede både forløbet og spillets univers til at matche faglige mål, som de selv definerede. Der er derfor ikke kun stor forskel på at anvende spildesigns i kraft deres forskellige spilmekanikker, kompleksitet og tilpasningsmuligheder til undervisningen, men også på de måder, hvorpå undervisere didaktiserer spil og tilpasser dem lokale målsætninger.

\section{Fire didaktiske tilgange}

Jeg vil nu gennemgå dansk forskning i fire didaktiske tilgange til digitale spil i undervisningen, dvs. anvendelse af henholdsvis læringsspil, kommercielle computerspil, gamification og design af spil. Undervejs vil jeg eksemplificere gennem centrale artikler i Læring Og Medier samt fra min egen forskning. De konkrete nedslag er ikke dækkende for al den danske forskning på området, men er valgt for at eksemplificere de didaktiske muligheder og begrænsninger, der knytter sig til hver af de fire tilgange.

\section{Læringsspil}

Den didaktiske anvendelse af læringsspil tager afsæt i digitale spil som er specifikt designede til undervisningsbrug, og det er den digitale spiltype, som er mest udbredt i undervisningen. Jeg vil her skelne mellem didaktiske tilgange til tre forskellige underkategorier af læringsspil: 1) simple færdighedsbaserede læringsspil, som primært anvendes til f.eks. sproglæring, repetition eller træning af motoriske færdigheder, 2) mere avancerede læringsspil (også kaldet "serious games"), der anvendes bruges til at simulere og undersøge komplekse sammenhænge, og 3) it-støttede læringsspil, der indbefatter forskellige typer af pervasive games, debatspil og rollespil, hvor spillernes interaktion i det fysiske rum understøttes af en computer.

De færdighedsbaserede læringsspil er relativt udbredte i uddannelsessystemet i form af forskellige typer af matematiktræningsspil som Grand Prix Multiplication, edutainment spil som ABCiTY eller quiz programmer som Kahoot. I betragtning af hvor udbredte de færdighedsbaserede læringsspil er i undervisningen, findes der relativt sparsom forskning, som undersøger deres didaktiske muligheder og begrænsninger. Et af de færdighedsbaserede spil som er blevet studeret i dansk sammenhæng er 
Mingoville, der er udviklet til begynderundervisning i engelsk som fremmedsprog (Hansbøl \& Meyer, 2011). Spillet distribueres til et globalt marked og kan tilpasses mange forskellige læringskontekster både til brug i undervisningen og derhjemme. Studiet viser, at selvom Mingoville lægger op til bred anvendelse på en global skala, så afhænger spillets læringsmæssige værdi i høj grad af, hvordan spillet introduceres og anvendes i lokale læringskontekster. Det er langt fra kun selve spildesignet, men også den didaktiske rammesætning af spillet, der afgør, om det kan bidrage positivt til sproglæring.

I modsætning til de færdighedsbaserede læringsspil, der ofte består af isolerede aktiviteter som den lærende selv kan vælge imellem, er de mere avancerede læringsspil ofte udviklet som aktiviteter, der skal indgå i længere undervisningsforløb. Et godt eksempel, som er publiceret i Læring Og Medier, er studiet af Dilemmaspillet, der er udviklet til undervisning i arbejdsmiljø på erhvervsskolerne (Pedersen et al., 2016). Her bliver spilleren mødt med en række dilemmaer med forskellige svarmuligheder og feedback, som giver anledning til efterfølgende refleksion og bearbejdning. Studiet påpeger, at spillet godt stå alene som en isoleret læringsoplevelse, men giver bedst udbytte, hvis det anvendes som en del af et længere forløb sammen med en række andre undervisningsmaterialer.

Det samme kan siges om spillene i serious game serien Global Conflicts, hvor spilleren skal bevæge sig rundt i 3D univers og undersøge konflikter i brændpunkter verden over. Læringsspillene er udviklet til undervisning i dansk, samfundsfag og historie i udskolingen og gymnasieniveau og lægger op til at indgå som en del af større undervisningsforløb om emnet. På basis af observationer i en række klasser i både Danmark, Norge og England var det tydeligt, at spilserien især appellerede til de elever, som gerne ville fordybe sig i læsningen af spillets dialoger, mens andre elever oplevede en skuffelse over, at "skolespillet" ikke havde tilstrækkeligt action (Hanghøj, 2011). Det vidner om vigtigheden af at lave forventningsafstemning mellem undervisere og elever, når man anvender læringsspil med et grafisk udtryk, der minder om de kommercielle computerspil. De fleste lærere i studiet havde en forventning om, at spillet primært ville appellere til de drenge, der spillede meget computerspil i deres fritid. Observationerne viste dog, at spillet netop blev afvist af den elevgruppe, som ud fra spillets trailer forventede en åben og actionpræget 3D spilverden i stil med Grand Theft Auto.

Et af de steder hvor den danske forskning i spil og læring adskiller sig fra den internationale forskning er, at der herhjemme er foretaget forholdsvis mange studier af it-støttede læringsspil, som er den tredje underkategori af læringsspil. Betegnelsen dækker over en bred vifte af multiplayer spil, der kobler spilleres fysiske interaktion og dialog i grupper med brug af computeren til at finde og bearbejde information. De hybride spilformater skal ofte tilpasses til lokale fysiske omgivelser og flere af de itstøttede læringsspil inddrager elementer af rollespil i form af roller, forhandling og forestillede scenarier, der bl.a. hænger samen med en stærk dansk (og nordisk) tradition for at spille rollespil.

Som eksempler på studier af it-støttede læringsspil vil jeg nævne en undersøgelse af debatspillet Spillet om magten (Hanghøj, 2008), hvor eleverne skal agere som politiske partier i en valgkamp og lave research på udvalgte hjemmesider som afsæt for mundtlige debatter, før de til sidst stemmer på hinanden og danner ny regering. Et andet eksempel er studiet af læringsspillet Benspænd (Misfeldt, 2010), hvor studerende arbejder gruppevist med processtyring af byggeprojekter med afsæt i interaktive Gantt kort samtidig med, at spillerne kan give modstanderne benspænd. Et tredje eksempel er et studie af det it-støttede rollespil Drabssag/Melved, hvor spillerne skal bruge naturvidenskabelige kompetencer til at opklare et mord, hvor de både finder information på computeren og anvender klasserummet som laboratorie for kriminaltekniske undersøgelser (Magnussen, 2008). Endelig vil jeg fremhæve et studie af det omfattende "event" Tough Road, som er udviklet til undervisning i gymnasiet, der kombinerer fysisk rollespil og forhandlinger med transaktioner gennem et computersimuleret finansmarked og udsendelse af sms'er på elevernes mobiletelefoner (Ejsing-Duun et al., 2013). Spillet kan rumme op til 120 deltagere ad gangen, der gennem otte forskellige roller undersøger konsekvenser af deres handlinger for den globale kaffeproduktion - lige fra kaffebøndernes høst i den tredje verden over salg på verdensmarkedet til at blive drukket på caféborde. Spillets monstrøse udfaldsrum gør det 
muligt at få indsigt i komplekse kausale sammenhænge i global handel på tværs af de forskellige aktører i værdikæden, som klassen derefter kan viderebearbejde i undervisningen.

Kort sammenfattet vidner forskningen i de it-støttede læringsspil om et stort engagement hos deltagerne, der arbejder gruppevist om at udforske og diskutere udfaldet af spillenes scenarier. I modsætning til de skærmbaserede læringsspil, hvor underviseren ofte står på sidelinjen, får underviseren her en mere aktiv rolle som facilitator af spillernes interaktioner, der understøttes af computerbaserede informationer. Samtidig er der tale om spilformater, der kan være relativt komplekse at anvende, og som sigter mod brede faglige kompetencemål. Dermed har underviseren ofte mindre overblik over de lærendes individuelle progression end i de skærmbaserede læringsspil.

Som det fremgår af ovenstående eksempler kan dansk forskning dokumentere stor variation i anvendelsen af digitale læringsspil. De forskellige underkategorier bygger samtidig på relativt forskellige antagelser om læring. De skærmbaserede læringsspil er ofte singleplayer spil, hvor der er fokus på at lære afgrænsede færdigheder eller udvikle kognitive og affektive forståelser af bestemte problemstillinger. Omvendt tager de it-støttede læringsspil afsæt i multiplayer formater, der lægger op til bredere udforskning af problemer, hvor deltagerne sammen skal konstruere ny viden i gensidig interaktion. I begge tilfælde afhænger værdien af spillene i høj grad af, hvordan dialogen før, under og efter spilaktiviteterne rammesættes og faciliteres af underviseren (Arnseth et. al, 2018).

\section{Kommercielle computerspil}

Den anden didaktiske tilgang omhandler brugen af kommercielle computerspil i undervisningen $-\mathrm{f}$.eks. i form af actionprægede skydespil som Counter-Strike, strategispil som Civilization, kreative konstruktionsspil som Minecraft eller puzzle adventures som LIMBO. I dansk sammenhæng kan den forskningsmæssige interesse for kommercielle computerspil og læring spores tilbage til Jessens (2001) etnografiske beskrivelser af børns praksisfællesskaber og legekultur omkring computerspil. Siden har der været flere danske studier af, hvordan man kan integrere kommercielle computerspil i den formelle undervisning. Mest kendt er Simon Egenfeldt-Nielsens (2005) ambitiøse undersøgelse af, hvordan man kan anvende det komplekse strategispil Europa Universalis II som en del af gymnasiets historieundervisning. Studiet vidner især om de mange udfordringer, som er knyttet til at anerkende og forstå et computerspil som gyldigt læringsredskab i undervisningen på trods af, at spillet bygger på grundig historisk research af Europas historie i perioden mellem 1419-1820. Det er med andre ord ikke tilstrækkeligt at et kommercielt computerspil repræsenterer et relevant fagligt indhold; spillet skal også accepteres af lærere og elever som en legitim læringsressource i undervisningen.

I Læring Og Medier har der været publiceret forholdsvist få studier, der undersøger de didaktiske aspekter af at anvende kommercielle computerspil i undervisningen. Juel Larsen (2015) foretager en grundig læringsteoretisk analyse af StarCraft 2, som han anvender til at videreudvikle en ekspansiv læringsteori, men artiklen kobler ikke teorierne til didaktisk praksis. Derudover har jeg selv publiceret et studie i $L O M$, der på baggrund af lærerinterviews og efteruddannelse af undervisere beskriver nogle af de overvejelser, som lærere gør sig, når de skal didaktisere kommercielle spil og dermed skabe "oversættelser" på tværs af domæner inden for og uden for skolen (Hanghøj, 2012). Som eksempel vælger en lærer at udvikle et undervisningsforløb om genreskrivning i dansk, som tager afsæt i den gratis demo til gyserspillet Penumbra, hvor narrativet bæres frem gennem suspense og en creepy lydside. Læreren lader eleverne afprøve spillet i en mørk kælder under skolen, hvor de spiller med head sets. På baggrund heraf får eleverne til at opgave at beskrive en scene fra spillet, hvor de efterfølgende skal begrunde, hvordan deres bedste sætninger er skrevet i "gysersprog". Eksemplet demonstrerer hvordan læreren udviser game literacy, idet han har et indgående kendskab til gyserspillets mekanikker og virkemidler, men også gamemastering ved at iscenesætte skolens kælder som et relevant sted at spille et gyserspil som afsæt for elevernes indlevelse og genreforståelse (Bourgonjon \& Hanghøj, 2011). 
I min øvrige forskning har jeg gjort flere forsøg på at integrere computerspil i danskundervisningen f.eks. gennem brug af sandkassespillet Minecraft i indskolingen (Hanghøj, 2017a; Hanghøj, Møller \& Brok, 2018), co-op action rollespillet Torchlight II på mellemtrinnet (Hanghøj et al., 2018), samt puzzle adventure spillet $L I M B O$ i udskolingen (Hanghøj, 2017b). Resultaterne tyder på, at de kommercielle computerspil kan virke endog meget motiverende for både lærere og elever som afsæt for multimodale produktioner og skrivning i form af dagbøger eller meddigtningsøvelser.

Samtidig er det ofte tidskrævende at installere og anvende komplekse computerspil i undervisningen. Som eksempel endte alle fire skoler i Sæt skolen i spil projektet med at lave LAN opsætninger med switches og netværkskabler, fordi det ikke lykkedes at få multiplayer spil som Torchlight II og Minecraft til at fungere på skolernes lokale netværk. Tilsvarende giver skolernes stigende indkøb af billige computere med lav teknisk performance og høje krav til online sikkerhed væsentlige udfordringer i forhold til at kunne anvende kommercielle computerspil i undervisningen - en udfordring som til dels kan imødekommes ved, at eleverne selv medbringer computere med egne spil (Bring Your Own Device). Samtidig begynder enkelte spilproducenter at få øjne på de læringsmæssige muligheder i de kommercielle spil. Et godt eksempel er den "discovery mode", der er udgivet til Assassin's Creed Origins, hvor kampsekvenserne er fjernet, hvilket gør spillet velegnet til historieundervisning om det gamle Ægypten. Derudover sker der i disse år en opblomstring af esport som et relativt specialiseret undervisningstilbud på danske skoler, efterskoler, specialskoler og gymnasier, der ofte tager afsæt i konkurrenceprægede spil som Counter-Strike, Overwatch, Fortnite og FIFA. Der findes endnu begrænset forskning i de didaktiske muligheder og begrænsninger ved esport, men et dansk pilotprojekt beskriver, hvordan unge Counter-Strike udøvere oplever, at de gennem træningen udvikler 21st Century Skills i form af kommunikation og samarbejde (Nielsen \& Hanghøj, 2019).

Der eksisterer dog også væsentlig mindre krævende måder at tematisere kommercielle computerspil i undervisningen, som tager afsæt i de mange online paratekster, som omgiver spillene og den gamer kultur, som de er en del af (Apperley \& Beavis, 2011). Ved at producere spilguides og spiljournalistiske artikler (anmeldelser, reportager, baggrundsartikler og debatindlæg), kan elever få mulighed for både at trække på deres spilerfaringer og samtidig reflektere kritisk over, hvordan de vil kommunikere deres viden til konkrete modtagere. I min forskning arbejder jeg derfor på at udvikle konceptet Spiljournalist.dk, der både fungerer som et gratis magasin og danskfagligt læremiddel i forhold til at publicere elevers tekster om spil og spilkultur. De foreløbige resultater vidner om betydelig engagement i forhold til at skrive journalistik om spil - uanset om eleverne primært skriver ud fra egen interesse i emnet eller ud fra et ønske om at give deres kritiske meninger til kende (Hanghøj \& Nørgaard, 2019).

\section{Gamification}

Inden for de sidste ti år har der været stor interesse for at anvende forskellige former for gamification i undervisningen. Gamification er oprindelig opstået som et begreb inden for markedsføring og kan kort defineres som brugen af spilelementer i ikke-spil kontekster (Deterding et al., 2011). Dvs. at man i stedet for at anvende hele spilverdener nøjes med at anvende isolerede spilmekanikker som f.eks. badges, achievements eller leaderboards til at motivere de lærende til øget aktivitet. Gamification kan både praktiseres gennem analoge spilaktiviteter eller gennem brug af digitale gamification systemer. Nogle af systemerne som f.eks. ClassCraft eller ClassDojo er deciderede læringsplatforme med integrerede spilmekanikker, hvor underviseren selv skal oprette indhold samt facilitere og give feedback på spilaktiviteterne. Andre platforme som Khan Academy, Code Academy eller Duolingo leverer bestemte former for indhold (matematik, programmering, fremmedsprog), der også kan tilgås uden for undervisningen. I princippet kan man "gamificere" mange forskellige typer af læringsindhold med de samme spilteknologier, hvad enten det drejer sig om at lære anatomi, sprog, regnearter eller programmering. Den store interesse for gamification skyldes primært, at der er tale om forholdsvis simple og generiske spilmekanikker, der kan virke mindre krævende at anvende end komplekse 
spilverdener. Samtidig gør systemerne det muligt at samle mange forskellige typer af data ind fra de lærende og følge deres progression.

I Læring Og Medier har Ahler og Bader (2012) undersøgt brugen af gamification på Fysioterapeutuddannelsen. De studerende blev motiveret af muligheden for at teste sig selv gennem Study Quiz app'en, men det gav især mening at anvende app’en, når det faglige indhold blev knyttet tæt til undervisningen. Samtidig viste studiet også, at underviseren spiller en central rolle i forhold til at motivere de studerende til at anvende quizzen forud for undervisningen. I et andet studie i $L O M$ har Christensen et al. (2016) studeret brugen af badges som en del af et større online kompetenceudviklingsforløb for undervisere på videregående uddannelser. Her blev det tydeligt, at der var en positiv sammenhæng mellem oplevelse af badges som motiverende faktor for de undervisere, der gennemførte modulet. Omvendt var der også en studerende, der oplevede brugen af badges som "hundetræning", dvs. som en behavioristisk tilgang til læring.

Ovenstående eksempler vidner om, at gamification teknikker ofte har en umiddelbar positiv effekt på de fleste studerendes motivation. Samtidig har Lieberoth (2015) i et eksperimentelt studie påvist en umiddelbar positiv motivationseffekt ved slet og ret at rammesætte en aktivitet som et "spil", uanset om der reelt er tale om et spil. Den positive motivationseffekt ved gamification kan derfor let vise sig at være flygtig over et længere undervisningsforløb, hvis spilaktiviteterne ikke bliver koblet meningsfuldt til undervisningen med løbende tilpasning til de studerendes interesser og faglige formåen.

På trods af de mange muligheder for at integrere gamification i undervisningen er der ofte begrænset variation i de didaktiske tilgange til at arbejde med spilelementer. I et nyligt review af forskningen i gamification, viser Majuri et al. (2018), at der primært anvendes achievements og progression som bærende spilmekanikker, mens sociale og narrative spilelementer ikke anvendes i nævneværdig grad. På den måde kommer de didaktiske tilgange til gamification ofte til at fremme læringsaktiviteter, der svarer til tilegnelse af viden gennem færdighedsprægede læringsspil, selvom gamification i princippet kunne anvendes til at stille de lærende over for en bred vifte af forskellige udfordringer. Brugen af løsrevne spilmekanikker i gamification kritiseres samtidig for at reducere spilaktiviteter til instrumentelle øvelser, hvor de legende elementer forsvinder (Plass et al., 2015). Tilsvarende fremhæver Sanchez et al. (2017) i deres studie af gamification platformen ClassCraft, at det er afgørende, at underviseren kan inddrage gamification mekanikkerne som en del af en fleksibel og legende diskussionsramme i den lokale klasserumskontekst. Der mangler derfor mere forskning i, hvordan man kan arbejde med et bredere repertoire af gamification teknikker og nærmere undersøgelser af, hvordan gamification kan bidrage til meningsfuld undervisning.

\section{Design af spil}

Den sidste didaktiske tilgang til digitale spil i undervisningen fokuserer på redskaber, som sætter de lærende i stand til selv at designe spil. Det kan f.eks. ske gennem brugen af det visuelle programmeringssprog i Scratch eller andre programmer til spildesign som Gamemaker eller Unity. Denne konstruktionistiske tilgang til spil og læring, hvor man lærer i en kombination mellem at rekonstruere sin viden om verden og materialisere idéerne i konkrete spildesigns, henter især inspiration hos MIT pionérer som Seymour Papert, Mitchel Resnick og Yasmin Kafai.

Designtilgangen til spil og læring har i dansk sammenhæng fået stor opblomstring i de seneste år. Den stigende interesse hænger sammen med de mange tiltag for at arbejde med designprocesser, innovation og entreprenørskab i undervisningen gennem forskellige former for maker spaces, fablabs og innovation camps rundt om i landet. Samtidig er der fornyet interesse i at lære børn programmering - f.eks. i Coding Pirates bevægelsen og det kommende skolefag Teknologiforståelse - der ofte tager afsæt i at arbejde med udvikling af forskellige typer spildesigns. 
Læring gennem design af spil danner baggrund for flere artikler i Læring Og Medier. Majgaard (2012) studerer eksempelvis, hvordan ingeniørstuderende designer spil gennem brug af værktøjet Gamemaker, hvor de gradvist bevæger sig fra at have en viden og forståelse af spil over konkret arbejde med at udvikle prototyper til at blive mere reflekterede spildesignere. Derudover beskriver både Capriani og Thestrup (2010) samt Nørager og Toft (2015), hvordan design af spil kan indgå i kreative og legende tilgange til at arbejde med forskellige typer af digitale teknologier. Begge studier vidner om stort engagement, ejerskab og idérigdom blandt deltagerne, hvor der primært er fokus på at facilitere og studere kreative udviklingsprocesser frem for at indfri specifikke faglige læringsmål.

Som tidligere nævnt tyder meget på, at design af spil er en effektiv tilgang til at udvikle studerendes 21st Century Skills (Qian \& Clark, 2016). Samtidig er det en stor didaktisk udfordring at skabe meningsfulde koblinger mellem spildesignaktiviteter og mere traditionelle fagligheder i uddannelsessystemet. På Quest to Learn skolen i New York, hvor elever siden 2006 har fået undervisning i at løse quests (udfordringer) gennem designtænkning og design af spil, har man taget konsekvensen heraf og udviklet et nyt curriculum, der betragter fag som systemer af viden, der kan forstås og udforskes gennem design af spilsystemer (Salen et al. 2011). Et af fagene hedder f.eks. "Codeworlds" og forbinder modersmålsfaget engelsk med matematik. Opfindelsen af nye fag er imidlertid ikke uden problemer, idet det kan være vanskeligt for lærere og elever at forstå fag som abstrakte systemer. Spildesignaktiviteterne i det danske forskningsprojekt GBL21: Game-Based Learning in the 21st Century (2017-2022) tager i stedet afsæt i de faglige mål for dansk, naturfag og matematik. Tanken er, at eleverne gennem en række faglige undervisningsforløb kan udvikle designkompetencer gennem design af analoge og digitale spil som svar på faglige designudfordringer (Hanghøj, Skott, Nielsen \& Ejsing-Duun, 2019). Uanset om man sværger til at arbejde med spildesign i valgfrie forløb uden for skolens formelle læringsrum, at danne nye fagkonstruktioner, eller at arbejde med nytænkning inden for de eksisterende faglige rammer, er der derfor tegn på, at de designorienterede tilgange til spil kommer til at få en større plads i undervisningen.

\section{Opsummering}

På baggrund af ovenstående gennemgang vil jeg nu opsummere didaktiske muligheder og begrænsninger ved de forskellige tilgange til at anvende digitale spil i undervisningen. Opsummeringen tager primært afsæt i et underviserperspektiv på spil og er er tænkt som en håndsrækning til de læsere, der selv ønsker at anvende digitale spil i undervisningen. Jeg har struktureret min opsummering ud fra følgende temaer, som går på tværs af de fire didaktiske tilgange til digitale spil: 1) koblinger til faglige mål, 2) læringssyn, 3) tilpasning til læringskontekst, og 4) underviserens rolle som facilitator.

\section{Koblinger til faglige mål}

Gennemgang viser, at der er stor forskel på, hvordan man gennem de fire didaktiske tilgange til spil kan skabe koblinger til faglige mål. Nogle anvendelser af læringsspil og gamification har et tydeligt fokus på at arbejde med afgrænsede faglige mål - f.eks. i forhold til at træne bestemte færdigheder inden for fremmedsprog (Mingoville) eller når studerende på Fysioterapeutuddannelsen bruger Study Quiz app'en til at teste deres viden og dyste mod andre. Brugen af andre typer af læringsspil som serious games og de it-støttede læringsspil har mindre fokus på færdigheder og større fokus på at udvikle faglige kompetencer - f.eks. ved at opstille og afprøve hypoteser til opklaring af mordgåder eller undersøge, hvilke argumenter som kan bruges til at vinde en valgkamp.

Som kontrast fremstår de faglige mål ofte mere utydelige eller mindre legitime, når undervisere arbejder med kommercielle spil som Minecraft, Torchlight II og Europa Universalis II, eller når de lærende selv skal designe spil gennem brug af programmer som Scratch eller Game Maker. Det kan derfor være krævende som underviser og som lærende at identificere og evaluere ud fra afgrænsede faglige mål, når man skal integrere kommercielle computerspil eller programmer til spildesign inden for rammerne af 
eksisterende fagkonstruktioner. Omvendt åbner multiplayer spil og design af spil en bred vifte af muligheder for at udvikle deltagernes evner som refleksive designere eller udvikle værdifulde 21st Century Skills som samarbejde, kommunikation, kritisk tænkning og kreativitet, der går på tværs af flere faglige sammenhænge. Opsummerende bør man som underviser derfor være bevidst om, hvordan de fire didaktiske tilgange til spil kobler til relativt forskellige typer af faglige mål.

\section{Læringssyn}

Det næste tema omhandler de antagelser om læring og viden, som er indlejret i de forskellige didaktiske tilgange og spildesigns. Med afsæt i Sfards (1998) skelnen mellem viden som tilegnelse og som deltagelse er det tydeligvis stor forskel på, om de forskellige didaktiske tilgange til spil i undervisningen primært lægger op til at tilegne sig viden - f.eks. gennem træning af sproglige færdigheder, repetition af viden og udvikling af kognitiv forståelse af arbejdsmiljø - eller om tilgangene primært forsøger at udvikle viden gennem deltagelse i fælles udforskning og problemløsning.

Som Sfard påpeger er det problematisk at fremhæve deltagelse eller tilegnelse som det rette perspektiv, eftersom begge syn på læring og videnskonstruktion udgør væsentlige måder at lære på. De færdighedsbaserede læringsspil kan eksempelvis være velegnede til at adressere specifikke behov hos studerende, ligesom de gruppebaserede spilaktiviteter kan bruges til fremme selvstændighed og sociale relationer mellem studerende. Det er samtidig vigtigt, at man som underviser gør sig klart, hvilke arbejdsformer, som man ønsker at fremme, når man anvender bestemte spil i undervisningen. Der kan således være flere lighedspunkter mellem de enkelte didaktiske tilgange til spil og beslægtede arbejdsformer uden spil, end der er på tværs af de fire didaktiske tilgange til spil. F.eks. kan man pege på flere fællestræk mellem at lære gennem færdighedsbaserede spil og arbejde med øvelsesopgaver i lærebogssystemer, eller mellem at igangsætte gruppebaserede spildesignaktiviteter og facilitere projektarbejde, end der er mellem at arbejde med færdighedsspil og design af spil.

Tilsvarende kan det være mere væsentligt at skelne mellem anvendelse af singleplayer og multiplayer spilformater end at skelne mellem brug af læringsspil, kommercielle spil, gamification eller design af spil. F.eks. er der interesante lighedspunkter i de måder elever går sammen i grupper og går til kamp mod monstre i co-op spillet Torchlight II, designer et fælles spil i Scratch og fører valgkamp ud fra partigrupper i Spillet om magten. I alle tre eksempler er eleverne nødt til at arbejde sammen i deres grupper om at klare bestemte udfordringer og derigennem konstruere fælles viden. Tilsvarende kan man påpege flere lighedspunkter mellem singleplayer spil på tværs af didaktiske tilgange - f.eks. mellem at kunne besvare multiple choice spørgsmål i et online quiz spil, bestå en test med repetitionsopgaver i et gamification forløb og at klikke på svarmuligheder i et dilemmaspil.

Samtidig er det vigtigt at understrege, at underviserens dialogiske rammesætning af spil ikke nødvendigvis skal bekræfte spillets antagelser om eller pædagogiske modeller for læring, men tværtimod gerne må udfordre spillenes svar, udfald og værdier i forhold til at fremme refleksion og udvikle de studerendes faglige forståelse. Spil kan derfor betragtes som dialogiske redskaber, der både kan fungere som en anledning til at afprøve forskellige former for viden og kunnen, og som afsæt for undervisning, hvor spillene indgår som aktører og stemmer i dialogen (Arnseth et al., 2018).

\section{Tilpasning til læringskontekst}

Gennemgangen viser, at der er markant forskel på, hvordan de fire forskellige didaktiske tilgange til spil i undervisningen kan tilpasses til bestemte læringskontekster. Jeg vil især fremhæve to aspekter: Spildesignets fleksibilitet og tidsforbrug til at forberede og spille spillet i undervisningen. Hvad angår det første aspekt, er der markante forskelle på, hvor meget og hvordan man som underviser kan forme et digitalt spil, så det kan matche specifikke behov og lokale målsætninger. Når man anvender digitale værktøj til at designe spil eller til at udvikle quiz opgaver er der tale om generiske redskaber, som kan 
tilpasses mange forskellige typer af formål. Omvendt kan man kun ændre på meget få tekniske designparametre, når man underviser med kommercielle computerspil som LIMBO, Europa Universalis II eller Torchlight II. Som underviser må man derfor overveje i hvor høj grad, at man ønsker at tilpasse sin undervisning til bestemte spildesigns - og omvendt undersøge i hvor høj grad, at man kan tilpasse et bestemt spilredskab til undervisningen.

Det næste aspekt angår tidsforbruget ved at anvende digitale spil i undervisningen, der fylder meget for praktikere, men som ofte er fraværende i forskningen. For nu at tage to yderpoler kan man sammenligne forberedelserne til at anvende Minecraft og anvende et quizprogram som Kahoot. For at anvende Minecraft kræver det, at underviseren først undersøger spillets grundlæggende mekanikker og vurderer, hvordan det kan være relevant for undervisningen. Dernæst skal spilles installeres og kunne fungere stabilt på skolens lokale netværk. Først der kan underviseren begynde at detailplanlægge, hvilket game map, der skal udvikles eller anvendes i forhold til at indfri bestemte faglige og pædagogiske mål. Til sammenligning kan man oprette en quiz på få minutter om stort set hvilket som helst emne. I en travl hverdag er det derfor ikke overraskende, at mange undervisere vælger at bruge simple spilteknologier ud fra hensyn til tidsforbrug. Af samme grund er det afgørende at have organisatorisk opbakning fra både ledelse, teknisk support og kollegaer, hvis man ønsker at anvende mere komplekse spil, som kan give stærke fælles oplevelser i undervisningen (Marklund, 2015).

\section{Underviserens rolle}

Som tidligere nævnt varierer underviserens rolle på tværs af de fire didaktiske tilgange. Brugen af de skærmbaserede læringsspil og gamification systemer giver underviseren mulighed for at træde tilbage fra spilaktiviteterne og monitorere de studerendes progression for så at følge op med feedback, hvor der er mangler eller udfordringer i den enkeltes faglige forståelse. Omvendt lægger de gruppeorienterede spilaktiviteter mere op til, at underviseren skal være en aktiv facilitator, der kan rammesætte dialogiske spilleregler for den gode samtale, give feedback på de studerendes arbejdsprocesser og moderere fælles diskussioner i plenum. Samtidig har undervisere - ligesom studerende - ofte bestemte præferencer i forhold til at anvende nogle former for spildesigns frem for andre, som både hænger sammen med underviserens eksisterende måder at undervise på og erfaringer med samt interesse for spil(teknologier). Brugen af spil kræver derfor, at man som underviser kan identificere og gøre sig fortrolig med de modeller for læring, som er indlejret i bestemte spildesigns, og derudfra vælger sin egen didaktiske tilgang til at anvende spillet i undervisningen.

\section{Konklusion}

Forhåbentlig har kortlægningen givet mere overblik over det brogede landskab af digitale spil i undervisningen, og dermed udvidet læserens forståelse af det didaktiske repertoire for anvendelse af spil. Tilbage står spørgsmålet: Hvilke af de fire didaktiske tilgange bør man som underviser vælge frem for andre? Som det fremgår af min gennemgang, er der ikke noget simpelt svar på det spørgsmål. Svaret afhænger i høj grad af, hvad der skal læres i form af bestemte former for viden, færdigheder og kompetencer - hvad enten målene er knyttet til bestemte fagligheder eller har et bredere pædagogisk sigte. Men svaret afhænger også af underviserens rammebetingelser og spilkyndighed i forhold til at vurdere, hvilke didaktiske muligheder og begrænsninger, som knytter sig til bestemte spildesigns i forhold til at indfri lokale faglige og pædagogiske mål. Og så afhænger svaret sidst men ikke mindst af, hvordan man som underviser ønsker og formår at bringe spillet til live sammen med deltagerne, og dermed rammesætte spillet som meningsfuld undervisning. 


\section{Referencer}

Ahler, T., \& Bader, S. (2015). Opsamling af studerendes svardata fra Study Quiz - en case beskrivelse. Tidsskriftet Laering Og Medier (LOM), 8(13).

Apperley, T., \& Beavis, C. (2011). Literacy into action: Digital games as action and text in the English and literacy classroom. Pedagogies: An International Journal, 6(2), 130-143.

Arnseth, H. C., Hanghøj, T. \& Silseth, K. (2018). Games as Tools for Dialogic Teaching and Learning: Outlining a Pedagogical Model for Designing and Researching Game-Based Learning Environments. In: Arnseth, H. C., Hanghøj, T., Misfeldt, M., Henriksen, T. D., Selander, S. \& Ramberg, R. (Eds.). Games and Education: Designs in and for Learning. New York: Sense Publishers, 123-139.

Bourgonjon, J. \& Hanghøj, T. (2011). What Does It Mean to Be a Game Literate Teacher? Interviews with Teachers Who Translate Games into Educational Practice. Proceedings of the $5^{\text {th }}$ European Conference on Game-Based Learning.

Caprani, O., \& Thestrup, K. (1). Det eksperimenterende fællesskab - Børn og voksnes leg med medier og teknologi. Tidsskriftet Laring Og Medier (LOM), 3(5).

Christensen, I.-M., Kjær, C., Lüders, B., Apollo, J. \& Hansen, P. (2016). Hvordan skabes et learning design, der motiverer og engagerer deltagerne i et online kompetenceudviklingsforløb? Tidsskriftet Laring Og Medier (LOM), 9(16).

Clarke, D. B., Tanner-Smith, E. E., \& Killingsworth, S. S. (2016). Digital games, design, and learning: A systematic review and meta-analysis. Review of Educational Research, 86(1), 79-122.

Deterding, S., Khaled, R., Nacke, L. E., \& Dixon, D. (2011). Gamification: Toward a definition. In CHI 2011 Gamification workshop proceedings. Vancouver BC, Canada.

Egenfeldt-Nielsen, S. (2005). Beyond edutainment: Exploring the educational potential of computer games. Ph.d. afhandling. København: IT-Universitetet.

Ejsing-Duun, S., Hanghøj, T. \& Skovbjerg, H. M. (2013). Cheating and Creativity in Pervasive Games i Learning Contexts. Proceedings of the $7^{\text {th }}$ European Conference on Game-Based Learning.

Gee, J. P. (2007). Good video games + good learning: Collected essays on video games, learning, and literacy. New York: Peter Lang.

Goffman, E. (1961). Fun in Games. I: Encounters: Two studies in the sociology of interaction. Oxford, England: Bobbs-Merrill.

Hanghøj, T. (2008). Playful Knowledge - An explorative study of educational gaming. Ph.d. afhandling. Odense: Syddansk Universitet.

Hanghøj, T. (2011). Clashing and emerging genres: The interplay of knowledge forms in educational gaming. Designs for Learning, 4(1), 22-33.

Hanghøj, T. (2012). Spilscenarier i undervisningen - præsentation af en didaktisk model. Tidsskriftet Laering Og Medier (LOM), 5(9).

Hanghøj, T. (2017a). Didaktiske tilgange til Minecraft i dansk. In: Hanghøj, T., Misfeldt, M., Bundsgaard, J., Fougt, S. S. \& Hetmar, V. (red.). Hvad er scenariedidaktik? Århus: Aarhus Universitetsforlag.

Hanghøj, T. (2017b). Computerspil - som multimodal tekst og som handlingsrum. Viden om literacy, 21, 42-48.

Hanghøj, T., Lieberoth, A., \& Misfeldt, M. (2018). Can cooperative video games encourage social and motivational inclusion of at-risk students? British Journal of Educational Technology, 49(4), 775-799.

Hanghøj, T., Møller, L. D. \& Brok, S. L. (2018). Skrivning i og rundt om Minecraft. I: Bundsgaard, J. Georgsen, M., Graf, S. T., Hansen, T. I. \& Skott, C. K. (red.). Innovativ undervisning med it. Forskning i de tre demonstrationsskolefors $\phi g$ - bind II. Århus: Aarhus Universitetsforlag.

Hanghøj, T. \& Møller, L. D. (2017). Den spilkompetente lærer - mellem game literacy og gamemastering. Learning Tech-Tidsskrift for laremidler, didaktik og teknologi, (3): 8-31.

Hanghøj, T. \& Nørgaard, J. (2019). Writing Game Journalism in School: Student Voices on Games and Game Culture. Proceedings of the Connected Learning Summit 2018, MIT, Boston.

Hanghøj, T., Skott, C. K., Nielsen, B. L. \& Ejsing-Duun, S. (2019). Developing Design Principles for GameRelated Design Thinking Activities. Proceedings of the $13^{\text {th }}$ European Conference on Game-Based Learning.

Hansbøl, M., \& Meyer, B. (2011). Shifting ontologies of a serious game and its relationships with English education for beginners. E-learning and Digital Media, 8(3), 228-246.

Jessen, C. (2001). Bфrn, leg og computerspil. Odense: Odense Universitetsforlag.

Juel Larsen, L. (2015). Computerspil og læring. Tidsskriftet Laring Og Medier (LOM), 8(13).

Juul, J. (2005). Half-Real: Video Games between Real Rules and Fictional Worlds. Cambridge, Massachusetts: MIT Press.

Kangas, M., Koskinen, A., \& Krokfors, L. (2017). A qualitative literature review of educational games in the classroom: the teacher's pedagogical activities. Teachers and Teaching, 23(4), 451-470. 
Lieberoth, A. (2015). Shallow gamification: Testing psychological effects of framing an activity as a game. Games and Culture, 10(3), 229-248.

Magnussen, R. (2008). Representational Inquiry in Science Learning Games. Ph.d. afhandling. Aarhus Universitet: DPU.

Majgaard, G. (2012). Design af computerspil i undervisningen: Fra indfødt spiller til reflekteret designer. Tidsskriftet Laring Og Medier (LOM), 5(9).

Majuri, J., Koivisto, J., \& Hamari, J. (2018). Gamification of education and learning: A review of empirical literature. I: Proceedings of 2nd International GamiFIN Conference, Pori, Finland.

Marklund, B. B. (2015). Unpacking Digital Game-Based Learning: The complexities of developing and using educational games. Ph.D. Dissertation. Skövde: University of Skövde

Misfeldt, M. (2010). 'Forestillet læringsvej' i IT-baserede pædagogiske udviklingsprojekter. Dansk Padagogisk Tidsskrift, 58(4), 42-52.

Nielsen, R. K. L. \& Hanghøj, T. (2019). Esports skills are people skills. Proceedings of the $13^{\text {th }}$ European Conference on Game-Based Learning.

Nousiainen, T., Kangas, M., Rikala, J., \& Vesisenaho, M. (2018). Teacher competencies in game-based pedagogy. Teaching and Teacher Education, 74, 85-97.

Pedersen, H., Bennedsen, G., \& Grytnes, R. (2016). Bare et spil? Perspektiver i at bruge serious games i arbejdsmiljøundervisningen i erhvervsskolerne. Tidsskriftet Laring Og Medier (LOM), 9(16).

Plass, J. L., Homer, B. D., \& Kinzer, C. K. (2015). Foundations of game-based learning. Educational Psychologist, 50(4), 258-283.

Qian, M., \& Clark, K. R. (2016). Game-based Learning and 21st century skills: A review of recent research. Computers in Human Behavior, 63, 50-58.

Salen, K., Torres, R., Wolozin, L., Rufo-Tepper, R., \& Shapiro, A. (2011). Quest to Learn: Developing the school for digital kids. The John D. and Catherine T. MacArthur Foundation Reports on Digital Media and Learning.

Salen, K. \& Zimmerman, E. (2003). Rules of Play: Game Design Fundamentals. Cambridge MA: MIT Press.

Sanchez, E., Young, S. \& Jouneau-Sion, C. (2017). Classcraft: From gamification to ludicization of classroom management. Education and Information Technologies, 22, 497-513.

Sfard, A. (1998). On two metaphors for learning and the dangers of choosing just one. Educational Researcher, 27(2), 4-13.

Toft, H., \& Nørgaard, R. (2015). Pla(y)ceskabelse: når børn og robotteknologi mødes. Tidsskriftet Laring Og Medier (LOM), 8(14).

Wouters, P., Van Nimwegen, C., Van Oostendorp, H., \& Van Der Spek, E. D. (2013). A meta-analysis of the cognitive and motivational effects of serious games. Journal of Educational Psychology, 105(2), 249.

Young, M. F., Slota, S., Cutter, A. B., Jalette, G., Mullin, G., Lai, B., Smeoni, Z., Tran, M. \& Yukhymenko, M. (2012). Our princess is in another castle: A review of trends in serious gaming for education. Review of Educational Research, 82(1), 61-89. 


\section{Forfatter}

\section{Thorkild Hanghøj}

Professor MSO

Aalborg Universitet - København

Forskningsgruppen KILD: Kommunikation, It og LæringsDesign

Co-coordinator, Center for Applied Game Research (CEAGAR) 